\title{
PENINGKATAN KOMPETENSI MAHASISWA MELALUI PEMBEKALAN KULIAH KERJA NYATA TEMATIK WIRA DESA (KKNT-WD)
}

\author{
Puji Muniarty ${ }^{1}$, Wulandari ${ }^{2}$, Della Saputri ${ }^{3}$ \\ Sekolah Tinggi Ilmu Ekonomi (STIE) Bima \\ e-mail: puji.stiebima@gmail.com, wulanbima.stiebima@gmail.com, \\ delsa991205@gmail.com
}

\begin{abstract}
Higher Education is an educational unit that organizes Higher Education. Universities are required to carry out the tridharma which consists of teaching, research and community service. Community service carried out by students in the form of Real Work Lectures (KKN) is a form of implementing collaborative student learning experiences through the implementation of theory and practice that will be applied to problems found in the village so that efficient, effective and appropriate solutions and strategies can be determined to improve the economic well-being of the community. To carry out the Wira Desa Thematic Real Work Lecture (KKNTWD) which has been determined by the Bima College of Economics (STIE), students who are declared to have passed the KKN registration administration must attend the KKNT-WD debriefing to improve knowledge competence before interacting with the community \& knowing the potential village for the purpose of preparing work programs during activities at the KKN location. The form of debriefing for KKNT-WD is carried out face-toface, lectures and questions and answers. The result of the debriefing is that students know and understand the general description and concept of the Wira Desa Real Work Lecture and its output in the form of publications in community service journals published online.
\end{abstract}

Keywords: Village Wira Thematic Real Work Lectures, Briefing Materials, Publications

Peningkatan Kompetensi Mahasiswa melalui Pembekalan Kuliah Kerja Nyata Tematik Wira Desa (KKNT-WD) 


\section{ABSTRAK}

Perguruan Tinggi merupakan satuan pendidikan yang menyelenggarakan Pendidikan Tinggi. Perguruan tinggi wajib menjalankan tridharma yang terdiri atas pengajaran, penelitian dan pengabdian kepada masyarakat. Pengabdian kepada masyarakat yang dilalukan oleh mahasiswa dalam bentuk Kuliah Kerja Nyata (KKN) merupakan bentuk implementasi kolaborasi pengalaman belajar mahasiswa melalui implementasi teori dan praktek yang akan diterapkan dalam permasalahan yang ditemukan di desa sehingga dapat ditetapkan solusi dan straregi yang efisien, efektif dan tepat guna meningkatkan kesejahteraan ekonomi masyarakat. Untuk melaksanakan Kuliah Kerja Nyata Tematik Wira Desa (KKNT-WD) yang telah ditetapkan oleh Sekolah Tinggi Ilmu Ekonomi (STIE) Bima mahasiswa yang dinyatakan lolos secara administrasi pendaftaran KKN wajib mengikuti pembekalan KKNT-WD untuk meningkatkan kompetensi pengetahuan sebelum berinteraksi dengan masyarakat \& mengetahui potensi desa untuk tujuan penyusunan program kerja selama kegiatan dilokasi KKN. Bentuk pembekalan KKNT-WD dilaksanakan secara tatap muka, ceramah dan tanya jawab. Hasil dari pada pembekalan tersebut yaitu mahasiswa mengetahui sekaligus memahami gambaran umum serta konsep Kuliah Kerja Nyata Wira Desa serta luarannya dalam bentuk publikasi dalam jurnal pengabdian kepada masayarakat yang dipublish secara online.

Kata Kunci: Kuliah Kerja Nyata Tematik Wira Desa, Materi Pembekalan, Publikasi

\section{A. PENDAHULUAN}

Perubahan peradaban manusia akhir-akhir ini berjalan sangat cepat dipacu oleh perkembangan teknologi khususnya teknologi informasi, terlebih dengan adanya pandemi Covid-19 sehingga membutuhkan perubahan perilaku manusia. Perubahan ini pada akhirnya berdampak juga terhadap permintaan pasar akan kualitas Sumber Daya Manusia (SDM) pembangunan. Pendidikan Tinggi sebagai pencetak SDM unggul ikut bertanggungjawab dalam menyiapkan SDM yang dibutuhkan. Program Merdeka Belajar-Kampus Merdeka adalah program Kementerian Pendidikan dan Kebudayaan yang bertujuan untuk 
memperkuat kompetensi lulusan, mendorong mahasiswa untuk menguasai berbagai keilmuan yang berguna untuk memasuki dunia kerja dan memberikan kesempatan bagi mahasiswa untuk memilih mata kuliah yang akan mereka ambil. Kampus Merdeka merupakan wujud pembelajaran di Perguruan Tinggi yang otonom dan fleksibel sehingga tercipta kultur belajar yang inovatif, tidak mengekang dan sesuai dengan kebutuhan mahasiswa.

Berbagai macam kegiatan kreatif yang akan dimotori oleh mahasiswa dan didampingi oleh berbagai institusi maupun lembaga yang akan mendukung kegiatan ini serta ada pelaporan untuk memberikan assessment terhadap setiap daerah apakah daerah tersebut sudah memiliki ketangguhan desa terhadap Covid-19. Untuk itu aakan tercipta ide kreatif yang ada di daerah di dokumentasikan untuk bisa disampaikan ke masyarakat umum untuk menjadi pendorong daerah lain untuk ikut KKN Tematik.

Berdasarkan Undang-Undang Republik Indonesia Nomor 12 Tahun 2012 tentang Pendidikan Tinggi pasal 1 ayat 9 menyatakan bahwa Tridharma adalah kewajiban Perguruan Tinggi untuk menyelenggarakan Pendidikan, Penelitian dan Pengabdian Kepada Masyarakat. Kemudian dijelaskan pula pada ayat 11 bahwa pengabdian kepada masyarakat adalah kegiatan sivitas akademika yang memanfaatkan Ilmu Pengetahuan dan Teknologi untuk memajukan kesejahteraan masyarakat yang mencerdaskan kehidupan bangsa. Pada Perguruan Tinggi pelaksanaan pengabdian kepada masyarakat yang dapat dilakukan melalui Kuliah Kerja Nyata (KKN). Salah satu Kuliah Kerja Nyata yang dilaksanakan saat ini oleh masing-masing institusi yaitu Kuliah Kerja Nyata Tematik (KKNT).

Peningkatan Kompetensi Mahasiswa melalui Pembekalan Kuliah Kerja Nyata Tematik Wira Desa (KKNT-WD) 
Kuliah Kerja Nyata Tematik (KKNT) merupakan suatu bentuk pendidikan dengan cara memberikan pengalaman belajar kepada mahasiswa untuk hidup di tengah masyarakat di luar kampus, yang secara langsung bersama-sama masyarakat mengidentifikasi potensi yang yang menangani masalah sehingga diharapkan mampu mengembangkan potensi desa/ daerah dan meramu solusi untuk masalah yang ada di desa. Kegiatan KKNT diharapkan dapat mengasah softskills kemitraan, kerjasama tim lintas disiplin/ keilmuan (lintas kompetensi) dan leadership mahasiswa dalam mengelola program pembangunan di wilayah pedesaan. Program Kuliah Kerja Nyata Tematik (KKNT) yang dilakukan oleh Sekolah Tinggi Ilmu Ekonomi (STIE) Bima yaitu bertemakan Kuliah Kerja Nyata Tematik Wira Desa (KKNT-WD) karena hal ini selaras dengan visi STIE Bima yaitu Menjadikan Sekolah Tinggi Ilmu Ekonomi (STIE) Bima sebagai lembaga pendidikan yang mencetak Sumber Daya Manusia siap pakai dan berkiwa entrepreneurship. Selain itu di tahun 2013 STIE Bima dianugerahkan sebagai kategori perguruan tinggi berkembang berbasis kreativitas menuju kampus kelas dunia dan diudukung dengan pada tahun 2019 mahasiswa meraih hibah Program Kreativitas Mahasiswa Bidang Kewirausahaan.

Kuliah Kerja Nyata Wira Desa (KKNT-WD) merupakan kolaborasi tridharma berupa teori dan praktek oleh mahasiswa untuk mitra sasaran sangat penting. Namun sejauh ini mahasiswa yang akan mengikuti KKNT-WD wajib mengikuti pembekalan KKN terlebih dahulu karena pada dasarnya mahasiswa yang akan menjadi peserta KKNT-WD masih belum mengetahui gambaran umum KKNT-WD, identifikasi potensi desa, dan bentuk pengabdian dan pemberdayaan 
masyarakat yang akan ditetapkan dalam program kerja kegiatan KKNTWD selama berada dilokasi. Oleh sebab itu pembekalan kuliah kerja nyata sangat diperlukan sebelum calon peserta KKNT-WD STIE Bima diterjunkan sesuai dengan lokasi yang telah ditetapkan oleh institusi sebelumnya. Adapun tujuan pembekalan Kuliah Kerja Nyata mahasiswa:

1. Menciptakan kondisi siap mental. fisik dan konsepsional bagi calon peeserta Kuliah Kerja Nyata Tematik Wira Desa (KKNT-WD).

2. Memberikan bekal pengetahuan dan keterampilan praktis kepada calon peeserta $\mathrm{KKN}$, khususnya tentang teori, strategi, pendekatan, metodologi dan seperangkat materi lain yang terkait langsung dengan program Kuliah Kerja Nyata Tematik Wira Desa (KKNT-WD).

Kuliah Kerja Nyata Wira Desa (KKNT-WD) diharapkan mampu meningkatkan kompetensi softskills dan hardskills mahasiswa dalam menumbuhkan kembagkan potensi ekonomi desa melalui pemberdayaan masyarakat dengan membina dan mendampingi kegiatan-kegiatan usaha di desa yang kurang dan atau tidak produktif baik usaha individu atau kelompok, usaha yang sudah ada dan atau usaha yang baru akan dikembangkan sehingga unit-unit usaha tersebut akan berkembang menjadi unggulan desa dan menuju desa wirausaha secara berkesinambungan dan berkelanjutan serta pengelolaan potensi lokal desa yang bernilai ekonomis sebagai sumber pendapatan bagi masyarakat. Penyelenggaraan Kegiatan Kuliah Kerja Nyata Tematik Wira Desa (KKNT-WD) Sekolah Tinggi Ilmu Ekonomi (STIE) Bima diharapkan dapat menjadi akselerasi peningkatan sinergitas dan harmonisasi hubungan institusional antara Pemerintah, Perguruan Tinggi dan masyarakat untuk peningkatan performa pembangunan, 
sedangkan bagi lembaga-lembaga swasta yang terlibat dengan kegiatan KKNT-WD diharapkan menjadi media dan partner perwujudan tanggungjawab sosial terhadap masyarakat dan untuk luaran kegiatan daripada kegiatan KKNT-WD yaitu publikasi dalam bentuk jurnal pengabdian kepada masyarakat yang diterbitkan secara online.

\section{B. PELAKSANAAN DAN METODE}

Pembekalan Kuliah Kerja Nyata Tematik Wira Desa (KKNT-WD) Sekolah Tinggi Ilmu Ekonomi (STIE) Bima dilaksanakan selama hari sabtu-minggu tanggal 17-18 Juli 2021 yang berlokasi di Auditorium STIE Bima yang dihandel oleh panitia KKNT-WD dan pemateri sesuai dengan keahlian bidangnya masing-masing serta bentuk kegiatan yaitu ceramah dan tanya jawab yang diatur oleh moderator. Sasaran kegiatan ini yaitu mahasiswa yang memenuhi syarat untuk memprogramkam mata kuliah kerja nyata. Metode pelaksanaan kegiatan Pembekalan Kuliah Kerja Nyata Tematik Wira Desa (KKNT-WD) Sekolah Tinggi Ilmu Ekonomi (STIE) Bima dilakukan melalui beberapa tahap yang terdiri atas (1) tahap persiapan dengan melakukan rapat koordinasi panitia dan persiapan keperluan selama pelaksanaan pembekalan KKNT-WD seperti penyempurnaan buku pedoman KKNT-WD, pengecekan finalisasi peserta pembekalan KKNT-WD, pemateri pembekalan KKNT-WD, kelengkapan administrasi peserta KKNT-WD seperti daftar hadir dan kartu peserta, kelengkapan peralatan sound system dan lain sebagainya, (2) tahap pelaksanaan yaitu penjelasan beberapa materi pembekalan Kuliah Kerja Nyata Tematik Wira Desa (KKNT-WD) oleh pemateri yang ditunjuk melalui surat tugas dari LPPM STIE Bima dan (3) tahap evaluasi yaitu dalam hal ini panitia 
KKNT-WD berkoordinasi dengan pemateri untuk mengirimkan soal evaluasi KKNT-WD dan setelah itu panitia mengirim soal evaluasi ke masing-masing googleclass peserta pembekalan KKNT-WD. Kegiatan pembekalan ini bertujuan memberikan materi $\mathrm{KKN}$, memperkenalkan apa itu KKNT-WD, memberikan gambaran program KKNT-WD dan memotivasi mahasiswa menjalani KKNT-WD

\section{HASIL DAN PEMBAHASAN}

Rapat persiapan kegiatan pembekalan Kuliah Kerja Nyata Tematik Wira Desa (KKNT-WD) STIE Bima yang dilakukan oleh panitia ada beberapa hal yang perlu dibenahi dan dipersiapkan seperti revisi bagian dari isi buku pedoman KKNT-WD, penetapan nama-nama peeserta KKNT-WD dan teknis pelaksanaan selama pembekalan berlangsung serta perlengkapan meja, kursi, proyektor, dan sounsistem diruang auditorium. Karena pembekalan ini masih dalam masa pandemi covid19 maka panitia benar-benar memperhatikan jarak kursi dan perlengkapan prokes sebagai bentuk antisipasi jika ada dari sebagian peserta yang tidak membawa masker dan tetap memperhatikan penyediaan handsanitizer selama kegiatan berlangsung.

\section{Gambar 1.}

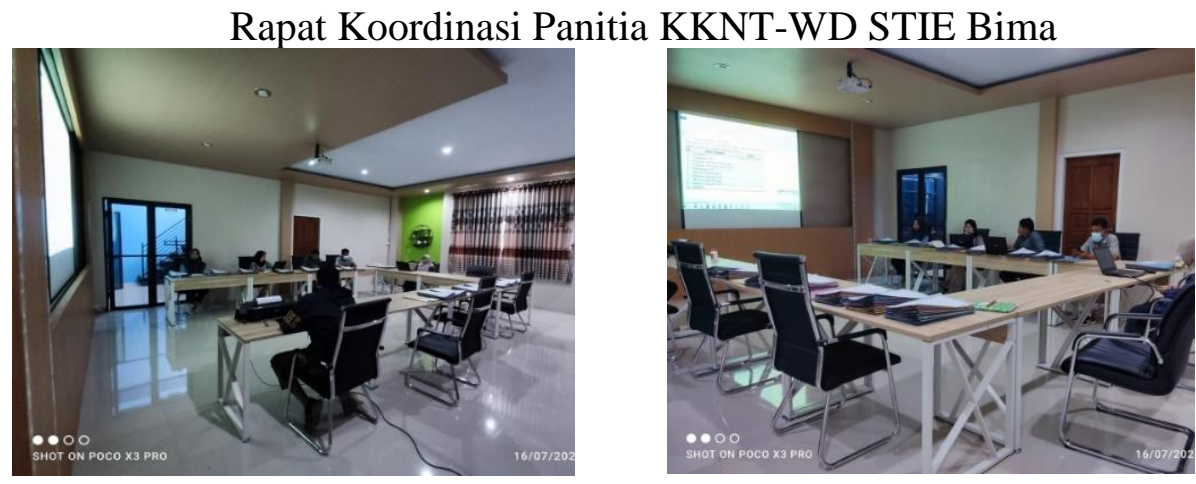

Peningkatan Kompetensi Mahasiswa melalui Pembekalan Kuliah Kerja Nyata Tematik Wira Desa (KKNT-WD) 
Oleh sebab itu untuk mencapai kompetensi pemahaman mahasiswa peserta pembekalan KKNT-WD panitia sudah menyiapkan buku pedoman KKNT-WD dan materi yang dikemas secara simpel dan praktis sehingga dalam penyampaian materi oleh narasumber memberikan kemudahan mahasiswa untuk memahami dan mengimplementasikan beberapa penjelasan tersebut dalam mengidentifikasi dan atau memetakan potensi desa dan penyusunan program kerja selama kegiatan KKNT WD berlangsung. Adapun materi yang dibawakan oleh masing-masing narasumber selama pembekalan yang dilaksanakan mulai tanggal 17 sd 18 Juli 2021 Jam 09.00 Wita sampai dengan selesai dengan tempat pelaksanaan di Auditorium STIE Bima sebagai berikut : (1) Gambaran Umum KKNT-WD, (2) Pengabdian Dan Pemberdayaan Masyarakat, (3) Pelaporan Dan Administrasi KKNT-WD dan (4) Publikasi Hasil Kegiatan Pelaksanaan KKNT-WD.

Gambar 2.

Narasumber Pembekalan KKNT-WD STIE Bima.

(a) Narasumber Materi

: Gambaran Umum

KKNT-WD

\&

Pengabdian

Dan

Pemberdayaam

Masyarakat

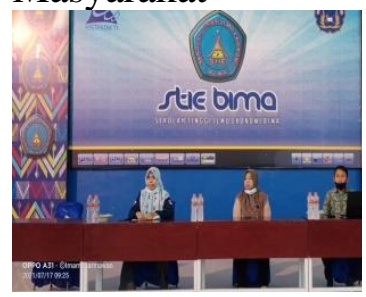

(b) Narasumber

Materi :

Pelaporan Dan

Administrasi

KKNT-WD

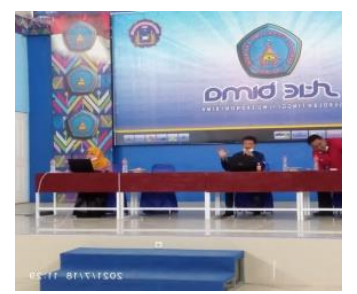

(c) Narasumber Materi : Publikasi

Hasil Kegiatan

Pelaksanaan

KKNT-WD

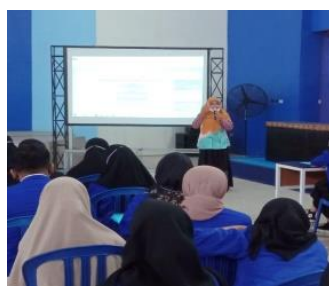


Hasil yang dicapai setelah para narasumber menjelaskan materi pembekalan KKNT-WD yaitu mahasiswa peserta pembekalan mengetahui gambaran dan konsep KKNT-WD yang ditetapkan oleh Sekolah Tinggi Ilmu Ekonomi (STIE) Bima. Selain itu mahasiswa sangat antusias dalam hal penyusunan program kerja dan banyak diantara peserta sampai ada yang bertanya teknis dan bagaimana cara menurunkan tingkat plagiasi publikasi hasil pengabdian kepada masyarakat. Ini menjadi langkah awal bagi mahasiswa untuk serius mengidentifikasi potensi desa lalu mendiskusikan bersama kelompok dan didampingi oleh dosen pembimbing kkn untuk menyusun dan menjalankan setiap program kerja selama berada di lokasi kuliah kerja nyata. Berdasarkan hasil wawancara ke beberapa peserta KKN yaitu mereka berharap dengan adanya publikasi sebagai luaran pelaksanaan program kerja KKNT-WD memberikan dampak yang positif bagi ekonomi daerah dan menambah khasanah pengetahuan bagi mahasiswa khsuusnya dan pembaca pada umumnya serta mengharapkan pelaksanaan KKNT-WD dilakukan secara offline (luring). Faktor pendukung dari keinginan mahasiswa untuk segera terjun ke lokasi dan penyusunan publikasi yaitu ada beberapa mahasiswa peserta pembekalan yang sudah mempublikasikan hasil kegiatan pengabdian masyarakat pada jurnal pengabdian masyarakat.

\section{KESIMPULAN}

Secara umum tidak ditemukan kendala yang berarti selama pelaksanaan pembekalan Kuliah Kerja Nyata Tematik Wira Desa (KKNT-WD). Respon dan antusias yang tinggi dapat terlihat dengan adanya berbagai pertanyaan yang diajukan oleh mahasiswa peserta

Peningkatan Kompetensi Mahasiswa melalui Pembekalan Kuliah Kerja Nyata Tematik Wira Desa (KKNT-WD) 
pembekalan KKNT-WD selama kegiatan berlangsung. Luaran KKNTWD yang dijelaskan oleh narasumber dalam bentuk publikasi dalam bentuk jurnal pengabdian kepada masyarakat yang diterbitkan secara online merupakan bentuk laporan terbaru dari hasil KKN yang akan dilaksanakan oleh mahasiswa Sekolah Tinggi Ilmu Ekonomi (STIE) Bima. Walaupun dalam kondisi pandemi Covid-19 mahasiswa berharap kegiatan pelaksanaan KKNT-WD dilaksanakan secara offline (luring) dan tidak dilakukan secara online. 


\section{DAFTAR PUSTAKA}

Basuki, K. (2019). Peranan Kuliah Kerja Nyata. ISSN 2502-3632 (Online) ISSN 2356-0304 (Paper) Jurnal Online Internasional \& Nasional Vol. 7 No.1, Januari - Juni 2019 Universitas 17 Agustus 1945 Jakarta, 53(9), 1689-1699.

Fuada, S. (2021). Pelatihan Zotero Guna Menunjang Luaran KKN Tematik Mahasiswa Universitas Pendidikan Indonesia Melalui Whatsapp Group. ABDIMAS: Jurnal Pengabdian Masyarakat, 4(1), 451-466.

Hakim, Z., Muttaqin, I., \& Mudarris, M. (2020). Revitalisasi Jembatan Desa sebagai Akses Aktivitas Perekonomian Desa Bangpindah Kecamatan Galis Bangkalan. Dharma: Jurnal Pengabdian Masyarakat, 1(1), 38-48.

Hidayat, N. (2019). Model Kuliah Kerja Nyata (KKN) Integratif Interkonektif Berbasis pada Pengembangan Masyarakat yang Produktif Inovatif dan Kreatif. Panangkaran: Jurnal Penelitian Agama Dan Masyarakat, 2(2), 219.

Himawati, I. P., Nopianti, H., \& Widiyarti, D. (2020). Optimalisasi peran mahasiswa melalui kuliah kerja nyata mandiri sebagai upaya mendukung pencegahan penularan Covid-19 pada masyarakat. Unri Conference Series: Community Engagement, 2, 379-385.

Ilmiah, J., Di, B. G., \& Tuban, K. (2021). Dharma: Jurnal Pengabdian Masyarakat Volume: 1, Nomor: 2, Juni 2021. Jurnal Pengabdian Masyarakat, 80-92.

Kholid.Mudarris, \& Masdar. (2020). Dharma: Jurnal Pengabdian Masyarakat Volume: 1, Nomor: 1, Desember 2020. 1(1), 61-72.

Mashudi, M., Suparyanto, D., \& Arisandi, B. (2020). Pendayagunaan Potensi Ekonomi Desa Paterongan Kecamatan Galis Melalui KKN

Peningkatan Kompetensi Mahasiswa melalui Pembekalan Kuliah Kerja Nyata Tematik Wira Desa (KKNT-WD) 
Mahasiswa STAIDHI Tahun 2020. Dharma: Jurnal Pengabdian Masyarakat, 1(1), 1-16.

Safitri, R., Amelia, R., \& Fahriani, F. (2016). Kuliah Kerja Nyata (KKN) Tematik Upaya Pemberdayaan Masyarakat Dalam Penerapan Teknologi Tepat Guna Berbasis Lingkungan Dan Ekonomi Di Kecamatan Merawang Kabupaten Bangka Provinsi Kepulauan Bangka Belitung. Pengabdian Kepada Masyarakat Universitas Bangka Belitung, 3(1), 58-69.

Sudarwati, Bagus, Cantika, Cikal, Choirul, Fully, Hafid, Hanung, Lukiyanto, Rizal, \& Sylivia. (2020). Jurnal BUDIMAS Vol. 02, No. 01, 2020. 02(01), 43-49.

Syardiansah. (2017). PENGEMBANGAN KOMPETENSI MAHASISWA ( Studi Kasus Mahasiswa Universitas Samudra KKN Tahun 2017 ). Jim Upb, 7(1), 57-68.

Buku Panduan Merdeka Belajar-Kampus Merdeka

Buku Pedoman KKNT-WD STIE Bima.

Undang-Undang RI Nomor 12 Tahun 2012. 